Paweł Marek Mucha

\title{
Czy kolejność ksiag Nowego Testamentu w kanonie jest przypadkowa?
}

Na pytanie zawarte w tytule tego artykułu zapewne prawie każdy da odpowiedź negatywną. Niemal wszyscy uważają, że taka, a nie inna kolejność ksiąg Nowego Testamentu nie jest przypadkowa. Nie chodzi tutaj o kwestię, dlaczego te, a nie inne księgi Nowego Testamentu znalazły się w kanonie (bo rozeznanie natchnionego charakteru tych ksiąg jest wyłącznym prawem Kościoła), ale chodzi o stwierdzenie faktu, że są one umieszczone w takiej kolejności zasadniczo już od II wieku. Zagadnienie to sprowadza się do udzielenia odpowiedzi na pytanie, czy księgi Nowego Testamentu są wymieniane w przypadkowej czy też w logicznie uporządkowanej kolejności.

Wielu będzie argumentować tę kolejność logicznym układem ksiąg. Rzeczywiście taką kolejność ksiąg Nowego Testamentu łatwo wytłumaczyć. Na pierwszym miejscu są wymieniane Ewangelie. Nie ma się zresztą czemu dziwić, bo są one najważniejszymi księgami Nowego Testamentu - w sposób bezpośredni przekazują naukę Pana Jezusa i całe Jego dzieło zbawcze. Po Ewangeliach są umieszczone Dzieje Apostolskie. Na to można się zgodzić, gdyż księga ta jest jedynym autentycznym świadkiem powstawania Kościoła, jego rozwoju i realizowania słów Pana Jezusa: „Będziecie moimi świadkami aż po krańce ziemi” (Dz 1, 8). Po Dziejach Apostolskich są Listy św. Pawła i katolickie (powszechne), a na końcu Apokalipsa. Miejsce Apokalipsy na końcu zbioru można łatwo zrozumieć, gdyż przedstawia ona przyszłe czasy, historię Kościoła aż do paruzji, umieszczenie zaś Listów św. Pawła przed katolickimi można wytłumaczyć ich powagą lub powagą ich autora. Takie wyjaśnienie porządku ksiąg Nowego Testamentu w kanonie jest rzeczywiście rozsądne ${ }^{1}$.

W Decretum de canonicis Scripturis Soboru Trydenckiego księgi Nowego Testamentu wymienione są w takim właśnie porządku - cztery Ewangelie (kolejno według: Mateusza, Marka, Łukasza, Jana), po nich są Dzieje Apostolskie, po Dziejach zaś Listy Pawłowe, po których wymienione są

\footnotetext{
${ }^{1}$ Por. J. Sickenberger, Die Geschichte des Neuen Testaments, Bonn 1934, s. 54-56.
} 
Listy Powszechne, a po nich na samym końcu Apokalipsa². Kolejność ksiąg wymienionych w dekrecie trydenckim jest oparta na wielu dokumentach historycznych. Nie jest to jednak jedyna kolejność znana z tradycji ${ }^{3}$. W wielu rękopisach zachodzą znaczne różnice, np. greckie majuskuły: A, B, C, wiele minuskuł, niektórzy pisarze Kościoła (Atanazy, Cyryl Jerozolimski) i synod w Laodycei z roku 363 znają następującą kolejność: Ewangelie, Dzieje Apostolskie, Listy katolickie, Listy Pawłowe, Apokalipsa.

Biorąc pod uwagę wielość wariantów kolejności ksiąg Nowego Testamentu w kodeksach, można by wysnuć wniosek, że kolejność ksiąg w dekrecie trydenckim jest raczej przypadkowa i nie wykluczająca innych, opartych również na przekazie historycznym. Rzuca się jednak w oczy fakt, że we wszystkich przypadkach Ewangelie umieszczano na początku, a Apokalipsę na końcu zbioru.

Porządek Mt, Mk, Łk, J oparty jest na niemal wszystkich kodeksach greckich, fragmencie Muratoriego, wielu pisarzach Kościoła (Ireneusz, Orygenes, Atanazy, Grzegorz z Nazjanzu) i niektórych synodach: Laodycejskim z roku 363 i Kartagińskim z roku 397. Nie dziwi więc fakt, że został on powszechnie przyjęty, chociaż w starożytności znano także inne kolejności, np. Mt, J, Mk, Łk ${ }^{4}$.

Te czasami znaczne różnice w kolejności ksiąg Nowego Testamentu są zupełnie zrozumiałe, jeśli weźmie się pod uwagę, że były one początkowo pisane w formie zwojów (volumen) i umieszczane jeden obok drugiego. Dopiero forma kodeksów (rodzaj książek) wprowadziła zasadnicze zmiany pod tym względem (jeden po drugim) i w miarę upływu czasu kolejność tę ustalano w sposób przyjęty w danej prowincji kościelnej5. Oznaczałoby to, że jednak kolejność ksiag Nowego Testamentu w kanonie jest - wbrew naszym przekonaniom przypadkowa. Nie można się jednak z takim stanowiskiem zgodzić.

W czasach poapostolskich łączono księgi w większe zbiory, które można podzielić na grupy: Corpus Evangelicum (obejmujący cztery Ewangelie), Corpus Paulinum (14 Listów św. Pawła) i Corpus Catholicum (zawierał Listy katolickie, czyli powszechne). Osobne zbiory stanowiły Dzieje Apostolskie i Apokalipsa ${ }^{6}$. Potwierdzenie owego Corpus Paulinum mamy już w Drugim Liście św. Piotra: „pod wpływem otrzymanej mądrości pisał do was najmilszy brat nasz Pawel, jak to zresztą czyni we wszystkich listach, w których są pewne

${ }^{2}$ Por. Enchiridion biblicum, 59.

${ }^{3}$ Por. E. DĄbrowski, Prolegomena do Nowego Testamentu, Poznań-Warszawa-Lublin 1959, s. 4-5.

${ }^{4}$ Por. E. Dąbrowski, Synopsa tacińsko-polska czterech Ewangelii, Poznań 1955, s. 9-16.

${ }^{5}$ Por. E. Dąbrowski, Prolegomena do Nowego Testamentu, dz. cyt., s. 5-6.

${ }^{6}$ Por. E. Dąbrowski, Prolegomena do Nowego Testamentu, dz. cyt., s. 47. 
myśli trudne do zrozumienia, a które ludzie nieuczeni i niestateczni paczą, podobnie jak i inne Pisma na swoją własną zgubę" (2 P 3, 15-16).

Sposób, w jaki Ojcowie Apostolscy (pod tym terminem rozumiemy echa tradycji apostolskiej zawartej w pismach: pseudo-Barnaby, Klemensa Rzymskiego, Ignacego z Antiochii, Polikarpa ze Smyrny, Hermasa, Papiasza, w Liście do Diogneta i Didache) cytują Pismo Święte, jest charakterystyczny. Przede wszystkim nie podają oni przeważnie imion autorów ksiąg7. Nawet św. Justyn w połowie II wieku cytuje wszystkie cztery Ewangelie, ale w żadnym miejscu nie podaje imienia autora ${ }^{8}$. Jest to znamienne, że do czasu nadania tytułów księgom Nowego Testamentu najważniejsza była autentyczność księgi, a nie jej autorstwo (tytuł), które było znane z tradycji. Od czasu nadania księgom tytułów sytuacja zmienia się diametralnie9

W drugiej połowie II wieku księgom Nowego Testamentu nadano tytuły, których do tej pory nie posiadały. Nie było bowiem potrzeby ich nadawania. Księgi były przepisywane ręcznie i dopiero kopiści zaczęli nadawać księgom Nowego Testamentu tytuły, które zachowały się do dzisiaj. Mogło to wynikać z potrzeby ich rozróżniania ${ }^{10}$, ale nie jest wykluczone, że w odpowiedzi na schizmatycki zbiór ksiąg Marcjona nadanie tych, a nie innych tytułów miało charakter apologetyczny ${ }^{11}$. Broniły one bowiem ich apostolskiego charakteru, co miało szczególne znaczenie. Właśnie w imię tradycji apostolskiej dokonano wyodrębnienia ksiąg natchnionych spośród całej masy pism będących wówczas w obiegu. Wystarczy zapoznać się z kanonem św. Ireneusza z Lyonu, Klemensa Aleksandryjskiego, Orygenesa i Tertuliana, żeby się przekonać, jak dochodziło do wyodrębnienia kanonu, i to w imię tradycji apostolskiej ${ }^{12}$.

Nadanie tytułów księgom miało zatem dwa cele: $\mathrm{z}$ jednej strony tytuły wskazywały na apostolskość tych ksiąg (ich pochodzenie od Apostołów bądź ich uczniów), z drugiej strony umożliwiały rozróżnianie ksiąg od siebie, a w konsekwencji dawały także możliwość umieszczania ich w odpowiedniej

${ }^{7}$ Por. E. Dąirowski, Prolegomena do Nowego Testamentu, dz. cyt., s. 47.

${ }^{8}$ Por. R. BARTNICKI, Ewangelie synoptyczne, geneza i interpretacja, Warszawa 1996, s. 22.

${ }^{9}$ Dla przykładu: imię Łukasza jako autora Ewangelii wyraźnie jest wymienione w drugiej połowie II wieku we fragmencie Muratoriego. Trzecia Ewangelia znana była jednak już Ojcom Apostolskim (św. Klemensowi Rzymskiemu, św. Ignacemu, św. Polikarpowi, św. Justynowi, Tacjanowi), cytowana jest także w Didache (koniec I wieku), ale u Ojców tych nigdzie nie występuje jednak imię Łukasza jako autora. Od drugiej połowy II wieku sytuacja zmienia się: imiona autorów są poświadczone (fragment Muratoriego, św. Ireneusz, Klemens Aleksandryjski, Orygenes, starożytne prologi łacińskie do Ewangelii, Euzebiusz) - por. F. Gryglewicz, Wstęp do Nowego Testamentu, Poznań-Warszawa 1969, s. 252-254.

${ }^{10}$ Por. np. F. Gryglewicz, Ewangelia wedtug św. Łukasza. Wstę - przekład z oryginatu komentarz, Poznań-Warszawa 1974, s. 40-41.

${ }^{11}$ Por. O. Cullmann, Zarys historii ksiag Nowego Testamentu, Warszawa 1968, s. 126-128.

${ }^{12}$ Por. E. Dąbrowski, Prolegomena do Nowego Testamentu, dz. cyt., s. 49. 
kolejności. Kiedy więc zebrano księgi Nowego Testamentu i włączono je do kanonu, z jednej strony zaszła potrzeba ich rozróżnienia, co było możliwe tylko poprzez uwidocznienie imion ich autorów (żeby rozróżnić między sobą cztery Ewangelie i 21 listów), z drugiej strony trzeba było wskazać na ich apostolskie pochodzenie, co odgrywało wielką rolę odnośnie do ich natchnionego charakteru. Wszyscy byli bowiem przekonani, że autorów poszczególnych ksiąg trzeba szukać wśród Apostołów lub uczniów apostolskich. Kiedy zostały nadane tytuły tym księgom, można je było przechowywać w odpowiedniej kolejności.

Pierwsze spisy ksiąg Nowego Testamentu należących do kanonu i wymienianych według tytułów w pewnej kolejności pojawiają się w drugiej połowie II wieku i na początku III wieku i są napisane w języku greckim: fragment Muratoriego (mamy tekst łaciński, pisany językiem ludowym, zdradzającym grecki oryginał, którego jest tłumaczeniem), św. Ireneusz (140-202), Klemens Aleksandryjski (150-215) i Orygenes (185-255). Znamienne jest to, iż są one zgodne z obecnym kanonem.

Najstarszym przekazem o kanonie Nowego Testamentu (choć niekompletnym) jest fragment Muratoriego, który został odkryty w 1740 roku przez bibliotekarza Ambrozjany Ludwika Muratoriego (stąd nazwa). Powstał on w drugiej połowie II wieku. Niezależnie od tego, czy jest to urzędowy dokument Kościoła Rzymskiego, czy też nie, to stan kanonu uznawanego w owym czasie w Rzymie jest bardzo wymowny ${ }^{13}$ :

- cztery Ewangelie: wymieniona jest wprawdzie trzecia i czwarta, ale zachowany początek wskazuje jednoznacznie na treść wierszy zaginionych;

- Dzieje Apostolskie;

- 13 Listów św. Pawła (brak Listu do Hebrajczyków);

- Listy katolickie (tylko List Judy i dwa Listy św. Jana);

- Apokalipsa św. Jana.

Jeśli chodzi o Ewangelie, to zachowany początek wskazuje na następujący ich porządek: Mt, Mk, Łk, J. Taki porządek Ewangelii przedstawiają także: św. Ireneusz, Orygenes, Euzebiusz Cezarejski, św. Hieronim i św. Augustyn. Ojcowie Kościoła nie tylko wymieniają te Ewangelie w takiej, a nie innej kolejności, ale jeszcze sugerują lub wręcz twierdzą, że w takiej kolejności zostały one napisane. Nie wiadomo, czy na podstawie czasu powstania tych ksiąg wymieniają je w takim porządku, czy na podstawie kolejności tych ksiąg w zbiorze (kanonie) Nowego Testamentu przypisują im taką właśnie chronologię powstania ${ }^{14}$. Jeśli te Ewangelie rzeczywiście

\footnotetext{
${ }^{13}$ Por. tamże, s. 53-59.

${ }^{14}$ Św. Augustyn wyraźnie akceptuje kolejność, jaką zgodnie z tradycją Ewangelie mają w kanonie, jako zgodną z czasem ich powstania (De consensu evangelistarum 1, 3, 1; 1, 2, 4;
} 
powstałyby w takiej kolejności, to w pełni uzasadniony byłby ich powyższy porządek w kanonie (Mt, Mk, Łk, J).

Jednak nie wszędzie Ewangelie są wymieniane w tej kolejności. Prologi Monarchiańskie (Pryscyliańskie) wymieniają bowiem Ewangelię według św. Jana na drugim miejscu, wyróżniając w ten sposób dzieła Apostołów od dzieł uczniów apostolskich (Mt, J, Łk, Mk) ${ }^{15}$. Chronologicznej zaś kolejności powstawania Ewangelii (Mt, Mk, Łk, J) przyjętej przez większość zaprzecza Klemens Aleksandryjski. Ten pierwszy uczony chrześcijański twierdzi, że najpierw powstały Ewangelie zawierające genealogie (Mt i Łk), po nich dopiero powstała Ewangelia według św. Marka, na samym zaś końcu Ewangelia według św. Jana ${ }^{16}$. Dlatego nie powinniśmy zakładać, że Ewangelie zostały umieszczone w kanonie według kolejności ich powstania (tzn. że nie mamy pewności, iż porządek Ewangelii w kanonie odzwierciedla ich chronologie powstania).

Na pewno pozostałe zbiory Nowego Testamentu (Listy św. Pawła, Listy katolickie, Dzieje Apostolskie, Apokalipsa) nie były umieszczane według chronologii ich powstania, i nie chodzi tutaj o poszczególne Listy w danym zbiorze i ich kolejność (dotyczy to Corpus Paulinum i Corpus Catholicum), lecz właśnie o te cztery wyżej wymienione zbiory. Wyraźnie wyodrębniono Corpus Evangelicum od pozostałych zbiorów: Corpus Paulinum, Corpus Catholicum, Dziejów Apostolskich i Apokalipsy (Ewangelii nie mieszano z pozostałymi zbiorami Nowego Testamentu, lecz zarezerwowano dla nich osobną przestrzeń). Wynikałoby z tego, że jednak porządek ksiąg Nowego Testamentu w kanonie jest przypadkowy...

Jednak kopiści po nadaniu tym księgom tytułów umieszczali je w takiej, a nie innej kolejności, i nie chodzi tutaj tylko o kolejność znaną z kanonu, ale w ogóle o pewną regułę porządkowania ksiąg Nowego Testamentu. Ta kolejność rzutowała później na porządek tych ksiąg w kodeksach. Wydaje się mało prawdopodobne, żeby chrześcijanie nadawali księgom przypadkowy porządek, lecz bardziej uzasadnione wydaje się założenie, że umieszczali te księgi według pewnej kolejności (reguły). Zauważyć można bowiem pewne logiczne uporządkowanie, które jest jednak mało dostrzegalne w języku polskim.

$1,3,5 ; 1,4,7)$, ale jego stanowisko jest trudne do przyjęcia, zwłaszcza że przeciwstawia się tradycji, która jednoznacznie uważała Ewangelię według św. Marka za spisane nauczanie św. Piotra, a nie streszczenie Mateusza - por. R. BARTNICKI, Ewangelie synoptyczne, geneza i interpretacja, Warszawa 1996, s. 38-39.

${ }^{15}$ Por. E. DĄBRowski, Synopsa łacińsko-polska czterech Ewangelii, dz. cyt., s. 13-14.

${ }^{16}$ Por. Eusebius Caesariensis, Historia Ecclesiastica 6, 14, 5-7; E. Dąbrowski, Synopsa tacińsko-polska czterech Ewangelii, dz. cyt., s. 12-13 (ale porządek pozostałych ksiąg ma zasadniczo ten sam, co obecny kanon). 
Otóż po przyjrzeniu się spisom ksiąg Nowego Testamentu we fragmencie Muratoriego, u Ireneusza, Klemensa Aleksandryjskiego i Orygenesa (jeśli chodzi o Listy - zbiorom Listów, a nie poszczególnym Listom) zauważymy zaskakującą właściwość: te księgi są wymieniane w alfabetycznej kolejności według ich tytułów (biorąc pod uwagę alfabet grecki, w którym są napisane te pierwsze wykazy ksiąg natchnionych). Ta kolejność jest jednak nie wstępująca, lecz zstępująca (tzn. nie są wymieniane od A do $\Omega$, lecz od $\Omega$ do

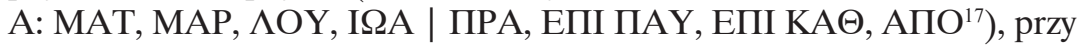
czym Ewangelie są osobnym zbiorem, wyodrębnionym spośród pozostałych:

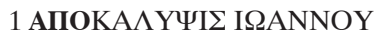 \\ 2 EIII $\Sigma$ TO $\Lambda$ AI KA@O $\Lambda$ IKAI \\ 3 EII $\Sigma$ TO $\Lambda$ AI IAY $\Lambda O Y$ \\ 4 ПIPA $\Xi E I \Sigma$ АПO $\Sigma T O \Lambda \Omega N$}

\begin{abstract}
5 ЕYАГГЕАION KATA IQANNHN
6 ЕYАГГЕАION KATA $\Lambda$ OYKAN

7 ЕYАГГЕАION КАТА MAPKON

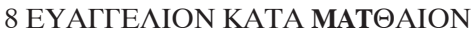

Tę zaskakującą właściwość alfabetycznej, zstępującej kolejności ksiąg w spisach tych Ojców Kościoła, a także w wielu kodeksach łatwo wytłumaczyć, jeśli się weźmie pod uwagę kodeksy i ich tworzenie. Jak już zostało wcześniej wspomniane, istniały pewne zbiory: Corpus Evangelicum, Corpus Paulinum, Corpus Catholicum, Apokalipsa i Dzieje Apostolskie. Tworząc kodeksy, umieszczano w nich księgi (zbiory) w alfabetycznej kolejności, wyodrębniając jednak Ewangelie spośród pozostałych ksiąg. Dokonano tego, biorąc pod uwagę tytuły ksiąg: najpierw wzięto księgę Apokalipsy (АПО),

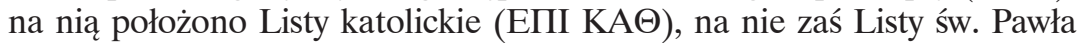
(ЕПІ ПАY), a na nie Dzieje Apostolskie (ПРА). Dopiero na samym końcu (co w efekcie tworzenia kodeksu daje jego wierzch, a więc początek tego kodeksu) umieszczono Corpus Evangelicum, czyli cztery Ewangelie, każdą z nich także według kolejności alfabetycznej ich tytułów: na Dzieje Apostolskie położono najpierw Ewangelię według św. Jana (ISA), na nią Łukasza ( $\Lambda \mathrm{OY})$, na tę zaś Marka (MAP), a na samym końcu Mateusza (MAT).

W ten sposób księgi, które przy tworzeniu kodeksu wzięto jako pierwsze, znalazły się na końcu kodeksu, a te, które brano jako ostatnie, znalazły się na samym początku kodeksu, tworząc jego wierzch (czyli kolejność ksiąg w kodeksach jest odwróceniem kolejności umieszczania ksiąg w kodeksie).

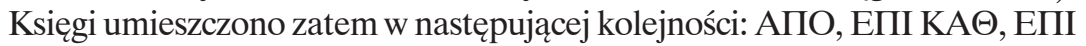

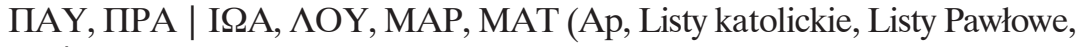
Dz | J, Łk, Mk, Mt). I tak otrzymano kolejność ksiąg kanonicznych Nowego Testamentu znaną z wielu dokumentów historycznych, a przede wszystkim ze spisów ksiąg Nowego Testamentu z końca II i początku III wieku, wymienianą

${ }^{17}$ Żeby nie powtarzać wielokrotnie całych długich tytułów ksiąg, a pokazać alfabetyczną kolejność tych ksiąg według ich tytułów w języku greckim, stosuję skróty: całe tytuły zastępuję trzema pierwszymi literami kluczowego słowa z tytułu - czasem dwóch kluczowych słów, jeśli wymaga tego dokładniejsze rozróżnienie tych ksiąg. 
przez greckojęzycznych starożytnych pisarzy chrześcijańskich, a więc u początków takich spisów (Mt, Mk, Łk, J | Dz, Listy Pawłowe, Listy katolickie, Ap).

W zasadzie księgi te nie musiały być od razu włączane w kodeks, bo samo już nadanie tytułów tym księgom umożliwiało ich uporządkowanie (nawet w formie zwojów) i ich umieszczanie w odpowiedniej kolejności na półce. Istotnym jest tutaj fakt, że u samego początku takich spisów umieszczano te księgi właśnie w takiej kolejności (alfabetycznej według ich tytułów). Można to łatwo wytłumaczyć: kiedy księgi otrzymały tytuły, można je było umieścić w odpowiednim porządku (obojętne czy to w kodeksie, czy w formie zwojów na półce). W żadnym wypadku nie chciano nadawać im przypadkowej kolejności, lecz uczyniono to w najprostszy sposób - opierając się na alfabetycznej kolejności tytułów tych ksiąg. Chronologiczna kolejność nie była brana w ogóle pod uwagę, czemu zresztą nie ma się co dziwić, bo w czasach poapostolskich najważniejsza była autentyczność dzieła, a nie jego autorstwo ani tym bardziej czas powstania. Na uwage zasługuje fakt, że najstarszy spis ksiąg Nowego Testamentu pochodzi z Rzymu (fragment Muratoriego) i zawiera właśnie taki porządek ksiąg, który nota bene jest zgodny z obecnym kanonem.

Za pomocą tego sposobu (umieszczania ksiąg w kanonie według alfabetycznej kolejności ich tytułów) można wytłumaczyć także inny porządek ksiąg Nowego Testamentu, a mianowicie: Ewangelie, Dzieje Apostolskie, Listy katolickie, Listy Pawłowe, Apokalipsa, który mógł być spowodowany nadaniem innych tytułów księgom ${ }^{18}$. Taki porządek ksiąg został przekazany przez greckie majuskuły: A, B, C, wiele minuskuł, niektórych pisarzy Kościoła (Atanazy, Cyryl Jerozolimski) i synod w Laodycei z roku 363.

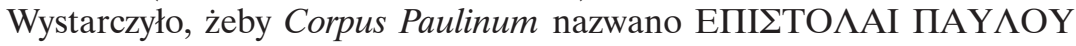

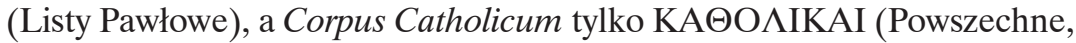
bez dodawania nazwy EПI $\Sigma$ TO $\Lambda$ AI) i zaraz po Apokalipsie umieszczano Listy Pawłowe, a dopiero po nich Powszechne (tworząc kodeksy):

\section{AIIOKA $\Lambda$ Y $\Psi$ I $\Sigma$ I $\Omega A N N O Y$ \\ 2 EIII $\Sigma$ TO $\Lambda$ AI ПIAY $\Lambda O Y$

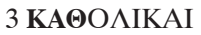 \\ 4 IIPA $\Xi E I \Sigma$ АПО $\Sigma T O \Lambda \Omega N$}

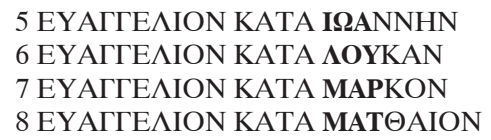

Sama nazwa „katolickie” jest bardzo stara i znana już antymontaniście Apolloniuszowi (zm. ok. 170). Użyta bez słowa „Listy” powoduje umieszczenie Listów katolickich po Listach Pawłowych, a przed Dziejami Apostolskimi - a więc przy składaniu kodeksu, księgi położono według

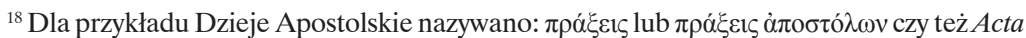
Apostolorum (fragment Muratoriego, Tertulian) albo Actus Apostolorum (Ireneusz, Tertulian, Cyprian, Augustyn) - por. E. DĄBrowski, Prolegomena do Nowego Testamentu, dz. cyt., s. 239. 
alfabetycznej kolejności ich tytułów, czyli w następującym porządku: AПO, ЕПI ПАY, КА

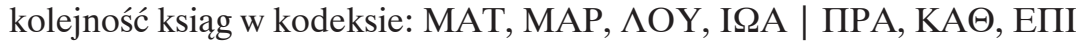
ПАY, АПО (Mt, Mk, Łk, J | Dz, Listy Powszechne, Listy Pawłowe, Ap).

Powyższe rozwiązanie wyjaśniające taką, a nie inną kolejność ksiąg w kodeksach (a co za tym idzie, w dzisiejszym kanonie) jest hipotetyczne, lecz nie pozbawione racjonalnych przesłanek. Znając sposób tworzenia kodeksów (umieszczanie ksiąg jedna po drugiej), można w łatwy sposób wytłumaczyć tę kolejność właśnie dzięki alfabetycznemu porządkowi ksiąg według ich tytułów, co było możliwe po nadaniu tym księgom tytułów. Zapewne nie do wszystkich wariantów kolejności ksiąg w kodeksach można tę metodę zastosować. Najstarsze spisy mają nieprzypadkowy porządek ksiąg, który został ściśle określony po nadaniu tym księgom tytułów i zebraniu ich w formie kodeksów zamiast dotychczasowych zwojów, co umożliwiło ich umieszczanie jednej po drugiej według alfabetycznej kolejności ich tytułów. Najważniejszym jest jednak fakt, że za pomocą tej zasady (umieszczania ksiąg w kodeksie, spisie według alfabetycznej kolejności tytułów tych ksiąg) łatwo jest wytłumaczyć porządek ksiąg Nowego Testamentu u początków takich spisów, a więc na przełomie II i III wieku (fragment Muratoriego, św. Ireneusz, Klemens Aleksandryjski, Orygenes).

Na uwagę zasługuje fakt, że kolejność ksiąg z kanonu (zaakceptowana przez Sobór Trydencki) jest taka sama, jak w najstarszych spisach Ojców Kościoła, a przede wszystkim zgodna z najstarszym takim spisem w Kościele rzymskim. Ten porządek ksiąg nie był przypadkowy, lecz logicznie uporządkowany, na podstawie czego można uważać obecny porządek ksiąg Nowego Testamentu w kanonie za autentyczny i nieprzypadkowy.

Poznań

PAWEŁ MAREK MUCHA

\section{Summary}

Is the order of the New Testament books in the canon random?

Decretum de canonicis Scripturis (Council of Trent) gives the following list of the canonical books of the New Testament: Matthew, Mark, Luke, John, Acts of the Apostles, Pauline Epistles, Catholic Epistles, Revelation. This order is based on many manuscripts, but is not the only one known. The Apostolic Fathers cite the books of the New Testament, but never give their titles. The books were only given titles in the late second century. The Muratorian fragment is the oldest document (the second half of the 2 nd century) which enumerates canonical books in an appropriate order. The important fact is that this list was prepared in the Roman Church and the order is in accordance with our canon. The Muratorian fragment presents the list of books in the reverse alphabetical order (from Z to A). It is a consequence of the tendency to order books alphabetically (not only in codices). Due to the fact that the oldest list of canonical books enlists them in the same order as we do in our canon and this order is not random, the order in our canon seems to be authentic. 